\title{
Beggar-Thyself or Beggar-Thy-Neighbour? : The Welfare Effects of Monetary Policy
}

\section{Engler, Philipp}

Freie Universität Berlin, School of Business \& Economics

2010

Engler , P \& Tervala , J 2010 , Beggar-Thyself or Beggar-Thy-Neighbour? The Welfare

Effects of Monetary Policy School of Business \& Economics Discussion Papers , no. 2010/6

, Freie Universität Berlin, School of Business \& Economics , Berlin . https://doi.org/10.2139/ssrn.1577119

http://hdl.handle.net/10138/39205

https://doi.org/10.2139/ssrn.1577119

submittedVersion

Downloaded from Helda, University of Helsinki institutional repository.

This is an electronic reprint of the original article.

This reprint may differ from the original in pagination and typographic detail.

Please cite the original version. 


\section{Beggar-Thyself or Beggar-Thy-Neighbour? \\ The Welfare Effects of Monetary Policy}

Juha Tervala

Philipp Engler

Schaol of Business \& Ecanamics

Discussion Paper

Econamics

2010/6

978-3-941240-18-6 


\title{
Beggar-Thyself or Beggar-Thy-Neighbour? The Welfare Effects of Monetary Policy
}

\author{
Juha Tervala and Philipp Engler*
}

March 12, 2010

\begin{abstract}
This paper examines whether monetary expansion is a beggarthyself or beggar-thy-neighbour policy. Obstfeld and Rogoff (1995) show that monetary expansion under producer currency pricing increases domestic and foreign overall welfare, in cases where the crosscountry substitutability is high. If the cross-country substitutability is low, then monetary expansion is a beggar-thyself policy that reduces domestic welfare and increases foreign welfare (Corsetti \& Pesenti 2001; Tille 2001). In this paper, we will show that regardless of whether the cross-country substitutability is high or low, monetary expansion is always a beggar-thyself policy in the short run.
\end{abstract}

Keywords: Open economy macroeconomics, monetary policy, beggarthyself, beggar-thy-neighbour

JEL classification: E32, E52, F30, F41

*Juha Tervala: Aboa Center for Economics and University of Turku, Assistentinkatu 7, 20014 Turun yliopisto, Finland, tel: +358-2-3336925, email: juha.tervala@utu.fi; Philipp Engler: Freie Universität Berlin, Boltzmannstr. 20, 14195 Berlin, Germany, tel: +49-3054632, email: philipp.engler@fu-berlin.de. 


\section{Introduction}

The U.S. Federal Reserve and the European Central Bank have implemented expansionary monetary policies during the recent global recession in an attempt to stimulate their economies. An important question about expansionary monetary policies is whether such a policy stance is beggar-thy-neighbour or beggar-thyself, that is, whether it is beneficial or detrimental for the domestic economy, and what the effects are for the rest of the world. With flexible exchange rates and open capital markets, a permanent increase in the supply of money depreciates the currency and increases exports and employment. From the perspective of the traditional Mundell-Fleming model, this policy is beggar-thy-neighbour, and is recommended to the domestic policy maker if increasing output is the policy goal.

Since the publication of the Redux model by Obstfeld and Rogoff (1995), the question of whether a permanent monetary expansion is welfare improving or not has been analysed in the framework of fully micro-founded twocountry models. ${ }^{1}$ The welfare measure employed is the discounted present value (DPV) of the change in utility of the domestic and foreign representative households. Obstfeld and Rogoff show that a monetary shock increases the DPV of utility by the same amount in both countries, in cases where the elasticity of substitution between goods produced in different countries (the cross-country substitutability) is the same as the elasticity of substitution between goods produced in the same country (the within-country substitutability). On the other hand, Corsetti and Pesenti (2001) and Tille (2001) find that the gains in domestic output are more than offset by deteriorating terms of trade, if the cross-country substitutability is lower than the withincountry substitutability. ${ }^{2}$

What has been missing until recently in this literature, however, was a

\footnotetext{
${ }^{1}$ Lane (2001) provides an early and extensive survey of the New Open Economy Macroeconomics literature. Lane and Ganelli (2003) focus on the exchange rate pass-through debate and the role of the current account in adjustment dynamics. Corsetti (2007) provides a more recent survey.

${ }^{2}$ Further contributions to this literature challenging the basic results of Obstfeld and Rogoff (1995) on the positive cross-country spillover effects of monetary policy shocks include Betts and Devereux (2000), Warnock (2003), and Tille (2008). Betts and Devereux (2000) show that under local currency pricing a country may improve its terms of trade and thus raise its consumption and welfare, at the expense of its neighbour. Warnock (2003) shows that a beggar-thy-neighbour effect can result in the presence of a home bias in consumption. More recently, Tille (2008) shed light on the role of cross-country holdings of different asset classes showing, inter alia, that cross-country equity holdings can reduce the net dividend payments to the rest of the world when the money shock increases real wages and reduces profits resulting in a positive welfare differential.
} 
thorough analysis of the evolution of welfare over time. ${ }^{3}$ The contribution of this paper is to go beyond the above-mentioned studies, which employ simultaneous one-step-ahead pricing, and to analyse the welfare effects of monetary policy over time. To do this, we extend these models with the Calvo-pricing mechanism.

The main finding of this paper is that the frameworks of Obstfeld and Rogoff (1995), Corsetti and Pesenti (2001), and Tille (2001) in the end generate a common result: A monetary shock is a beggar-thyself policy in the short run, no matter whether the cross-country substitutability is equal to or is smaller than the within-country substitutability. The intuition behind this result is the following: In all cases, a monetary shock causes an increase in domestic output without an equivalent increase in consumption. In addition, we show that a high value of the cross-country substitutability implies a higher decrease in domestic welfare in the short run. That is, the beggarthyself effect is strongest in the Obstfeld-Rogoff case. The main reason is that a high cross-country substitutability implies a strong expenditure switching effect. This causes a high response of output (employment) without an equivalent increase in consumption, due to a deterioration in the terms of trade and the accumulation of net external assets.

The rest of the paper is organised as follows: In section 2, we present the model. In section 3, we analyse the welfare effects of an unexpected shock to the domestic money supply, using illustrative numerical simulations. Section 4 concludes the paper.

\section{The Model}

In this section, we develop a standard New Open Economy Model in the tradition of the Redux model (Obstfeld \& Rogoff, 1995). ${ }^{4}$ The world economy consists of two countries: home and foreign. There is a continuum of firms and households that are indexed by $z \in[0,1]$. A fraction $n$ of these are located in the home country, while the remaining fraction $1-n$ are located in the foreign country. Nominal price rigidity is introduced by the mechanism proposed by Calvo (1983). This mechanism allows for an analysis of the welfare effects of monetary policy over time, which goes beyond the studies of Obstfeld and Rogoff (1995), Corsetti and Pesenti (2001), and Tille (2001),

\footnotetext{
${ }^{3}$ In a related paper, Tervala (2010) analyses the question of how the welfare effects of monetary policy over time depend on the currency of export pricing, using a version of the Betts-Devereux (2000) model.

${ }^{4}$ It is based on Betts and Devereux (2000), Pierdzioch (2006), Tille (2001), and Tervala (2010).
} 
which employ simultaneous one-step-ahead pricing.

\subsection{Households}

\subsubsection{Preferences}

All households have identical preferences. The utility function of the representative domestic household is given by $^{5}$

$$
U_{t}(z)=\sum_{s=t}^{\infty} \beta^{s-t}\left[\log C_{s}+\frac{\chi}{1-\varepsilon}\left(\frac{M_{s}}{P_{s}}\right)^{1-\varepsilon}-\frac{\ell_{s}(z)^{2}}{2}\right],
$$

where $\beta$ is the discount factor, $C$ is a consumption index (defined below), $\varepsilon$ and $\chi$ are positive parameters, $M$ is nominal money balances, $P$ is the consumer price index (defined below) and $\ell$ denotes the supply of labour. The overall consumption index is

$$
C_{t}=\left[n^{\frac{1}{\rho}}\left(C_{t}^{h}\right)^{\frac{\rho-1}{\rho}}+(1-n)^{\frac{1}{\rho}}\left(C_{t}^{f}\right)^{\frac{\rho-1}{\rho}}\right]^{\frac{\rho}{\rho-1}},
$$

where $C^{h}\left(C^{f}\right)$ is an index of domestic (foreign) goods and $\rho>0$ measures the elasticity of substitution between domestic and foreign goods. As in Tille (2001), this elasticity is referred to as the cross-country substitutability. The consumption indexes are defined as

$$
C_{t}^{h}=\left[n^{-\frac{1}{\theta}} \int_{o}^{n}\left(C_{t}^{h}(z)\right)^{\frac{\theta-1}{\theta}} d z\right]^{\frac{\theta}{\theta-1}}, \quad C_{t}^{f}=\left[(1-n)^{-\frac{1}{\theta}} \int_{n}^{1}\left(C_{t}^{f}(z)\right)^{\frac{\theta-1}{\theta}} d z\right]^{\frac{\theta}{\theta-1}},
$$

where $c^{h}(z)\left(c^{f}(z)\right)$ denotes consumption of domestic (foreign) good $z$ and $\theta>1$ is the elasticity of substitution between goods produced in the same country. Following Tille (2001), this is referred to as the within-country substitutability.

The optimal allocation of consumption between different types of goods is governed by the following equations:

$$
\begin{gathered}
C_{t}^{h}(z)=\left[\frac{p_{t}^{h}(z)}{P_{t}^{h}}\right]^{-\theta}\left[\frac{P_{t}^{h}}{P_{t}}\right]^{-\rho} C_{t}, \quad C_{t}^{f}(z)=\left[\frac{p_{t}^{f}(z)}{P_{t}^{f}}\right]^{-\theta}\left[\frac{P_{t}^{f}}{P_{t}}\right]^{-\rho} C_{t}, \\
C_{t}^{* h}(z)=\left[\frac{p_{t}^{* h}(z)}{P_{t}^{* h}}\right]^{-\theta}\left[\frac{P_{y}^{* h}}{P_{t}^{*}}\right]^{-\rho} C_{t}^{*}, \quad C_{t}^{* f}(z)=\left[\frac{p_{t}^{* f}(z)}{P_{t}^{* f}}\right]^{-\theta}\left[\frac{P_{t}^{* f}}{P_{t}^{*}}\right]^{-\rho} C_{t}^{*} .
\end{gathered}
$$

\footnotetext{
${ }^{5}$ For the foreign country, equivalent equations apply unless they are explicitly discussed.
} 
The prices and price indexes are denoted as follows: $p_{t}^{h}(z)\left(p_{t}^{f}(z)\right)$ is the domestic currency price of a domestic (foreign) good $z, P_{t}^{h}\left(P_{t}^{f}\right)$ is the price index of domestic (foreign) goods and $P_{t}$ is the domestic consumer price index. All of these price indexes are expressed in domestic currency terms. Analogously, for instance, $p_{t}^{* h}(z)\left(p_{t}^{* f}(z)\right)$ is the foreign currency price of a domestic (foreign) good. The law of one price holds for each good so that $p_{t}^{h}(z)=S_{t} p_{t}^{* h}(z)$, where $S$ is the nominal exchange rate (the domestic currency price of foreign currency). Therefore, the purchasing power parity holds: $P_{t}=S_{t} P_{t}^{*}$.

The domestic price indexes are given by

$$
\begin{gathered}
P_{t}^{h}=\left[n^{-1} \int_{0}^{n} p_{t}^{h}(z)^{1-\theta} d z\right]^{\frac{1}{1-\theta}}, \quad P_{t}^{f}=\left[(1-n)^{-1} \int_{n}^{1} p_{t}^{f}(z)^{1-\theta} d z\right]^{\frac{1}{1-\theta}} \\
P_{t}=\left[n\left(P_{t}^{h}\right)^{1-\rho}+(1-n)\left(P_{t}^{f}\right)^{1-\rho}\right]^{\frac{1}{1-\rho}} .
\end{gathered}
$$

\subsubsection{Budget Constraints and Optimal Behaviour}

The budget constraint of the representative domestic household is

$$
M_{t}+\delta_{t} D_{t}=D_{t-1}+M_{t-1}+w_{t} \ell_{t}-P_{t} C_{t}+\pi_{t}+P_{t} \tau_{t}
$$

Here, $\delta_{t}$ is the price of the bond $\left(\delta_{t}=\left(1+i_{t}\right)^{-1}\right.$, where $i_{t}$ is the nominal interest rate) that pays one unit of domestic currency in period $t+1, D_{t}$ denotes bonds held at the beginning of period $t, w$ is the nominal wage paid to the household in a competitive labour market, $\pi$ denotes the household's share of the nominal profits (dividends) of domestic firms, and $\tau$ is a transfer from the government (seigniorage revenues). All domestic households own an equal share of all domestic firms.

The capital market is integrated and the only internationally traded asset is a domestic currency denominated bond. ${ }^{6}$ Consequently, the budget constraint of a representative foreign household is

$$
M_{t}^{*}+\delta_{t} \frac{D_{t}^{*}}{S_{t}}=\frac{D_{t-1}^{*}}{S_{t}}+M_{t-1}^{*}+w_{t}^{*} \ell_{t}^{*}-P_{t}^{*} C_{t}^{*}+\pi_{t}^{*}+P_{t}^{*} \tau_{t}^{*} .
$$

The optimal behaviour of households is governed by the following equations:

$$
\begin{gathered}
\delta_{t} P_{t+1} C_{t+1}=\beta P_{t} C_{t}, \\
\delta_{t} P_{t+1}^{*} C_{t+1}^{*} S_{t+1}=\beta P_{t}^{*} C_{t}^{*} S_{t},
\end{gathered}
$$

\footnotetext{
${ }^{6}$ The aggregate asset-market-clearing condition is thus given by $n D_{t}+(1-n) D_{t}^{*}=0$.
} 


$$
\begin{gathered}
\ell_{t}=\frac{w_{t}}{C_{t} P_{t}}, \\
\ell_{t}^{*}=\frac{w_{t}^{*}}{C_{t}^{*} P_{t}^{*}}, \\
\frac{M_{t}}{P_{t}}=\left(\frac{\chi C_{t}}{1-\delta_{t}}\right)^{\frac{1}{\varepsilon}}, \\
\frac{M_{t}^{*}}{P_{t}^{*}}=\left(\frac{\chi C_{t}^{*}}{1-\frac{\delta_{t} S_{t+1}}{S_{t}}}\right)^{\frac{1}{\varepsilon}} .
\end{gathered}
$$

Equations (4) and (5) govern the optimal consumption over time. Equations (6) and (7) govern the optimal labour supply. Equations (8) and (9) show the money demand functions.

\subsection{Monetary Policy}

We abstract from government spending so that the transfers to households are given by

$$
\tau_{t}=\frac{M_{t}-M_{t-1}}{P_{t}}
$$

The money supply is assumed to follow a first-order autoregressive process described by the following equation:

$$
\hat{M}_{t}=\varphi \hat{M}_{t-1}+\epsilon_{M, t}
$$

where percentage changes from the initial steady state (denoted by the subscript zero) are denoted by hats $\left(\hat{M}_{t}=d M_{t} / M_{0}\right)$, and $\epsilon_{M, t}$ is an unpredictable shock to the money supply $\left(\epsilon_{M, t} \sim N\left(0, \sigma^{2}\right)\right.$.

\subsection{Supply Side: Firms}

\subsubsection{Profits and Demand}

All firms produce a differentiated good. The production function of the representative domestic firm is

$$
y_{t}(z)=\ell_{t}(z)
$$

where $y(z)$ is the total output of it and $\ell(z)$ is the labour input used by it.

The firm maximises profits

$$
\pi_{t}(z)=p_{t}(z) y_{t}(z)-w_{t} \ell_{t}(z)
$$


taking into account the above production function and the demand curve it faces

$$
y_{t}^{d}(z)=\left[\frac{p_{t}^{h}(z)}{P_{t}^{h}}\right]^{-\theta}\left[\frac{P_{t}^{h}}{P_{t}}\right]^{-\rho} C_{t}^{W},
$$

where $C_{t}^{W}$ is the world demand $\left(C_{t}^{W}=n C_{t}+(1-n) C_{t}^{*}\right)$. Therefore, the profits can be written as

$$
\pi_{t}(z)=\left[\frac{p_{t}^{h}(z)}{P_{t}^{h}}\right]^{-\theta}\left[\frac{P_{t}^{h}}{P_{t}}\right]^{-\rho} C_{t}^{W}\left(p_{t}^{h}(z)-w_{t}\right) .
$$

\subsubsection{Price Setting}

In the absence of nominal rigidities, the domestic firm maximizes profits with respect to $p_{t}^{h}(z)$, yielding the optimality condition

$$
p_{t}^{h}(z)=\frac{\theta}{\theta-1} w_{t} .
$$

This means that the price of the good is a markup, determined by the withincountry substitutability, over the marginal cost.

To be able to analyse the behaviour of welfare over time we assume the price setting structure of Calvo (1983). Each firm resets its price with a probability $1-\gamma$ in each period, independently of other firms and the time elapsed since the last adjustment. When setting its profit-maximizing price, the firm has to take into account that in every subsequent period there is a probability $0<\gamma<1$ that it will not be able to revise its price-setting decision. Therefore, the firm maximises the discounted value of expected real profits

$$
\max _{p_{t}^{h}(z)} V_{t}(z)=E_{t} \sum_{s=t}^{\infty} \gamma^{s-t} Q_{t, s} \frac{\pi_{s}(z)}{P_{s}},
$$

where $E$ denotes expectations, and $Q_{t, s}$ is a stochastic discount factor between period $t$ and period $s$. The first-order condition can be written as

$$
p_{t}^{h}(z)=\left(\frac{\theta}{\theta-1}\right) \frac{E_{t} \sum_{s=t}^{\infty} \gamma^{s-t} Q_{t, s}\left(\frac{C_{s}^{W}}{P_{s}}\right)\left(\frac{1}{P_{s}^{h}}\right)^{-\theta}\left(\frac{P_{s}^{h}}{P_{s}}\right)^{-\rho} w_{s}}{E_{t} \sum_{s=t}^{\infty} \gamma^{s-t} Q_{t, s}\left(\frac{C_{s}^{W}}{P_{s}}\right)\left(\frac{1}{P_{s}^{h}}\right)^{-\theta}\left(\frac{P_{s}^{h}}{P_{s}}\right)} .
$$

The log-linear version of equation (14) can be written as

$$
\hat{p}_{t}^{h}(z)=\beta \gamma E_{t} \hat{p}_{t+1}^{h}(z)+(1-\beta \gamma) \hat{w}_{t} .
$$

This equation simply states that the optimal price is the weighted average of the current and future nominal marginal costs. 


\subsection{Symmetric Equilibrium}

All firms in a country are symmetric, so that every firm that changes its price in any given period chooses the same output and sets the same price. The structure of price setting implies that in each period a fraction of firms $(1-\gamma)$ set a new price, while the remaining fraction keep their price unchanged.

The consolidated budget constraint of the home economy is derived by using equations (2), (10), and $(12)^{7}$ :

$$
P_{t} C_{t}=p_{t}^{h}(z) y_{t}(z)+D_{t-1}-\delta_{t} D_{t}
$$

The model is log-linearized around a symmetric steady state where all exogenous variables are constants and where initial net foreign assets are zero. Equations (6), (11) and (13) imply that in the initial level of employment is

$$
y_{0}=\ell_{0}=\left(\frac{\theta-1}{\theta}\right)^{\frac{1}{2}}
$$

\subsection{Choice of Parameter Values}

The choice of parameter values (if possible) follows Tille (2001), making it easier to compare the results of this model with those of his model. The within-country substitutability $(\theta)$ is set to 6 . The consumption elasticity of money demand $(1 / \varepsilon)$ is set to 1 . The relative size of the home country $(n)$ is set to 0.5 . The domestic money shock is permanent $(\varphi=1)$, and its size is unity $\left(\epsilon_{M, t}=1\right)$.

In the model of Tille (2001) all prices are preset for one period, which he interprets as one year, and fully flexible after that. In a model with the Calvo-price setting framework, it is more natural to interpret periods as quarters. Therefore, the discount factor $\beta$ is set to 0.99 . In addition, the price stickiness parameter $(\gamma)$ is set to 0.5 , implying an average delay between price adjustments of two periods. This is consistent with the findings of Bils and Klenow (2004).

The crucial parameter is the cross-country substitutability $(\rho)$. In the basic setting, we use a value of 6 so that it is equal to the within-country substitutability. In this case, the model replicates the results of Obstfeld and Rogoff (1995). This a natural benchmark to analyse the implication of lowering the cross-country substitutability to 3,1 and $0.5 .^{8}$

\footnotetext{
${ }^{7}$ The corresponding foreign equation is $P_{t}^{*} C_{t}^{*}=p_{t}^{* f}(z) y_{t}^{*}(z)-\frac{n}{1-n} \frac{D_{t-1}}{S_{t}}+\frac{n}{1-n} \delta_{t} \frac{D_{t}}{S_{t}}$.

${ }^{8} \mathrm{We}$ solve the model using the algorithm developed by Klein (2000) and McCallum (2001).
} 


\section{Welfare Effects of Monetary Policy}

\subsection{Method of Welfare Analysis}

In many New Open Economy Models - including Corsetti and Pesenti (2001), Obstfeld and Rogoff (1996), and Tille (2001) - all prices are fixed for one period and the economy reaches the new steady state after that period. In this case, the welfare effect is the short-run change in utility plus the discounted present value of the change in steady-state utility.

Due to staggered price setting in our model, a different method is needed to evaluate the welfare effects of monetary policy. We follow the same method as in Ganelli and Tervala (2010) and Tervala (2010). First, we study the change in period-by-period utility. Then, we calculate the discounted present value (DPV) of these changes. The change in utility in period $t$ is given by

$$
\hat{U}_{t}=\hat{C}_{t}-\ell_{0}^{2} \hat{\ell}_{t}
$$

The DPV of these changes is

$$
\hat{U}_{D P V}=\sum_{s=t}^{\infty} \beta^{s-t} \hat{U}_{s} .
$$

Figures 1 and 2 illustrate the changes in the period's utility. Table 1 shows these changes in the first period and in the steady state (SS). It also shows the DPV of the change in utility.

Table 1: Welfare Effects of Monetary Shocks

\begin{tabular}{|c|c|c|c|c|c|c|}
\hline & $\hat{U}_{1}$ & $\hat{U}_{1}^{*}$ & $\hat{U}_{s s}$ & $\hat{U}_{s s}^{*}$ & $\hat{U}_{D P V}$ & $\hat{U}_{D P V}^{*}$ \\
\hline$\rho=0.5$ & -0.062 & 0.13 & -0.0036 & 0.0036 & -0.47 & 0.57 \\
\hline$\rho=1$ & -0.13 & 0.19 & 0 & 0 & -0.20 & 0.31 \\
\hline$\rho=3$ & -0.30 & 0.36 & 0.0040 & -0.0040 & -0.0092 & 0.11 \\
\hline$\rho=6$ & -0.43 & 0.49 & 0.0057 & -0.0057 & 0.051 & 0.051 \\
\hline$\rho=9$ & -0.50 & 0.57 & 0.0065 & -0.0065 & 0.074 & 0.028 \\
\hline
\end{tabular}

\subsection{Basic Case}

Figure 1 (on page 18) shows the impulse response functions in the basic case, where the cross-country substitutability is equal to the within-country substitutability $(\rho=\theta=6)$. In this case, the model more or less replicates the results of Obstfeld and Rogoff (1995) and those of Tervala (2010). We regard this as a natural benchmark for the analysis in the next section.

In all figures, the vertical axes show percentage deviations from the initial steady state, except for the change in bond holdings, which are expressed as a 
deviation from initial consumption. The domestic terms of trade are defined as the relative price of domestic exports in terms of imports. Consequently, its terms of trade improve if this index rises. The change in the terms of trade is given by

$$
\widehat{T o T}_{t}=\hat{b}_{t}(z)-\widehat{S}_{t}-\hat{b}_{t}^{*}(z)
$$

where $\hat{b}_{t}(z)$ and $\hat{b}_{t}^{*}(z)$ are, respectively, the Calvo-weighted prices of domestic and foreign goods

$$
\begin{gathered}
\hat{b}_{t}(z)=\gamma \hat{b}_{t-1}(z)+(1-\gamma) \hat{p}_{t}^{h}(z), \\
\hat{b}_{t}^{*}(z)=\gamma \hat{b}_{t-1}\left(z^{*}\right)+(1-\gamma) \hat{p}_{t}^{* f}(z) .
\end{gathered}
$$

The Obstfeld-Rogoff case is well-known in the literature. We therefore focus on the behaviour of welfare over time. Staggered price setting does not change the equation governing the behaviour of the exchange rate. Therefore, it is determined by the same equation as in the Obstfeld-Rogoff model (1995, 640):

$$
\hat{S}_{t}=\left(\hat{M}_{t}-\hat{M}_{t}^{*}\right)-\frac{1}{\varepsilon}\left(\hat{C}_{t}-\widehat{C}_{t}^{*}\right) .
$$

In this way, the domestic money shock depreciates the exchange rate. This lowers the relative price of domestic goods, shifting global demand toward domestic goods and away from foreign goods, as long as prices are sticky. This expenditure-switching effect induces an increase in domestic output and a decrease in foreign output.

The shock lowers the real interest rate and global consumption increases. The households in both countries face the same real interest rate, implying that the shock changes their consumption profiles proportionately. However, the expenditure-switching effect causes a short-run increase in relative domestic consumption. The domestic households save part of this extra income by running a current account surplus. With higher long-run wealth, they decrease their labour supply. This decreases long-run output. A fall in the supply of domestic goods causes an improvement in their terms of trade.

Obstfeld and Rogoff (1995) show that a monetary shock increases overall utility (DPV of utility) by the same amount in the both countries, despite asymmetric output effects. The present model is consistent with this finding, as Table 1 shows. The liquidity effect of monetary policy increases world output, bringing it closer to its efficient level, and consequently increasing overall welfare in both countries. Moreover, the behaviour of the terms of trade provides the channel for sharing the benefits of monetary policy equally. The current account channel does affect overall welfare due to intertemporally optimizing households. 
In any case, the terms of trade and current account effects have implications for the behaviour of welfare over time, as is shown in a related paper (Tervala 2010). The accumulation of external assets and the deterioration in the domestic terms of trade implies that domestic consumption increases less than proportionally to output (employment). Monetary expansion, therefore, is a beggar-thyself policy in the short run.

Panel (g) in Figure 1 and Table 1 shows that domestic utility increases in the long run. Higher domestic wealth allows consumption to be higher than output (recall equation (15)). This current account effect and the improvement in the terms of trade have a favourable effect on consumption and, consequently, on welfare.

Panel (f) shows that the domestic shock increases foreign welfare in the short run. This is because of an increase in consumption and a fall in employment (output). In the long run, foreign households work more, due to lower long-run wealth, and output increases. This partly causes a deterioration of the foreign terms of trade. In addition, the foreign country must run a trade balance surplus to service the external debt. These current account and terms or trade effects have a negative effect on consumption and consequently on welfare in the long run.

\subsection{Low Cross-Country Substitutability}

In this section, we examine what happens to the evolution of welfare over time, when the value of the cross-country substitutability is reduced. In this exercise, it is below the benchmark value of 6 and of the within-country substitutability. As emphasised by Tille (2001, 422), this is likely to be most relevant from the empirical point of view: If countries specialise in the production of certain types of goods, the cross-country substitutability is likely to be smaller than the within-country substitutability. As the opposite case is less interesting, we report only the welfare results for $\rho=9$ in Table 1 .

Figure 2 and Table 1 show the effects of varying the cross-country substitutability. The results regarding the DPV of the change in utility are consistent with Tille (2001): A monetary expansion is a beggar-thyself policy only if there is less substitutability across countries than within. A monetary shock increases domestic output, but does not allow households to purchase enough additional consumption to offset the cost of their effort due to the deterioration in the terms of trade. The higher deterioration in the domestic terms of trade implies that the countries do not share the benefits of monetary policy equally, unlike in the Obstfeld-Rogoff case.

The present model, however, offers important insights into the welfare 
effects of monetary policy, once we focus on welfare dynamics. Table 1 and Figure 2 show that reducing the value of the cross-country substitutability implies a smaller decrease in domestic welfare in the short run. This happens despite a higher short-run deterioration in the domestic terms of trade. We also find that regardless of whether the cross-country substitutability is equal to or lower than the within-country substitutability, a monetary expansion is in the short-run always a beggar-thyself policy, reducing domestic welfare and increasing foreign welfare.

Let us focus first on the case of $\rho=3$. When domestic and foreign goods are poorer substitutes, the depreciation of the nominal exchange rate induces a weaker expenditure switching effect towards domestic goods and away from foreign goods. Both the increase of domestic relative to foreign output and the absolute increase in domestic output fall, when compared with the basic (Obstfeld-Rogoff) case. The latter implies that a money shock reduces domestic welfare by a lower amount than in the basic case.

As shown by Tille (2001), the cross-country substitutability is equal to the sum of the export and import elasticities, with respect to the terms of trade. And, if it is greater than one, then the Marshall-Lerner-Robinson condition holds and an exchange rate depreciation generates a current account surplus. In this model, the smaller the cross-country substitutability is, the smaller the increase in relative domestic income. Panel (e) of Figure 2 shows that households have a smaller incentive to lend internationally, when compared with the basic case. Therefore, the effect of the current account channel on domestic welfare becomes weaker. This is partly the reason why domestic welfare is smaller than the basic case in the first period after the shock.

The smaller value of $\rho$ implies that for any given change of demand, a bigger change in the terms of trade is needed to restore the equilibrium, as pointed out by Tille (2001). In his model, all goods prices are fixed in the short run and only the nominal exchange rate can change the terms of trade in the short run. In our model, two effects change the terms of trade. The smaller consumption differential across countries increases the depreciation of the nominal exchange rate (see equation (17)), as in Tille (2001). As this effect is rather small, the second effect is more important here. In our model, the relative price of domestic to foreign goods can also change among those firms that are able to change their prices in the first period (see equation (16)). When domestic and foreign goods are poorer substitutes, a given switch in demand requires a higher change in the optimal relative price of domestic and foreign goods, which implies that $\hat{b}_{t}(z)-\hat{b}_{t}^{*}(z)$ increases less in this case. Even though the adjustment mechanisms are different in our and Tille's model, in both models the deterioration in the terms of trade is higher than in the basic case. 
A higher deterioration in the terms of trade implies smaller domestic consumption. This causes a higher reduction in domestic welfare in the short run. But it is, however, more than offset by the smaller current account effect and the smaller increase in output, so that the decrease in domestic welfare is smaller than in the basic case in the short run.

The welfare effects in the long run are reduced as the increase in accumulated wealth is smaller. Table 1 also shows that the DPV of the change in utility is, consistent with Tille (2001), negative for $\rho=3$. The long-run positive effect of welfare is no longer large enough to compensate for the negative short-run effect.

The effect on foreign welfare is driven by the opposite effects following the terms of trade adjustment: The smaller expenditure switching effect implies a smaller decrease in foreign output, thereby reducing the short-run positive welfare effect. At the same time, the lower reduction of bond holdings decreases the long-run negative welfare effect, as less effort is needed to pay interest on the foreign debt.

Corsetti and Pesenti (2001) and Tille (2001) have shown that in case of $\rho=1$, a money shock does not generate current account imbalances and a deterioration in the domestic terms of trade reduces the DPV of the change in utility. In this case, the increase in demand for domestic goods does not increase the relative domestic income (and consumption) and consequently there is no incentive to lend internationally. The assumption, therefore, eliminates the current account channel. The results shown in Figure 2 and Table 1 are consistent with the results of the above-mentioned studies.

The present model, however, illustrates an important new point. Remember that one of the main results of Corsetti and Pesenti (2001) and Tille (2001) was that if the cross-country elasticity is unity, an exchange rate depreciation is a beggar-thyself policy, contrary to the welfare result of Obstfeld and Rogoff (1995). Panel (g) and Table 1 show that if the cross-country elasticity is unity, a fall in domestic welfare is much smaller than in the basic Obstfeld-Rogoff case in the short run. A weaker expenditure switching effect towards domestic goods implies that the increase in domestic output is smaller. Consequently, short-run domestic welfare falls by less than in the basic case.

Even when reducing $\rho$ to small values of below 1, the domestic welfare effect of monetary policy remains negative in the short run. The finding that monetary policy is beggar-thyself in the short-run is thus a robust result. In the case of $\rho=0.5$, domestic and foreign goods are poor substitutes, and a deterioration in the domestic terms of trade reduces the domestic sales revenue. This is because the Marshall-Lerner-Robinson condition does not hold. Therefore, a monetary expansion generates a fall in relative domestic income 
and consumption. The domestic household accumulates debt in the shortrun by running a current account deficit. This tends to increase short-run welfare. The terms of trade effect, however, dominates the current account channel to an extent that the increase in consumption is smaller than the increase in output in the short-run.

In this case, domestic households, with lower long-run wealth, increase their labour supply. This increases long-run output. An increase in the supply of domestic goods causes a permanent deterioration in the terms of trade. Therefore, Table 1 shows a fall in domestic utility in the long run. Lower domestic wealth implies that output must be higher than consumption. This current account effect and the deterioration in the terms of trade have a negative effect on consumption and consequently on welfare.

The contribution of this paper is to analyse the welfare effects of monetary policy over time, going beyond the studies of Obstfeld and Rogoff (1995), Corsetti and Pesenti (2001) and Tille (2001) which employ simultaneous onestep-ahead pricing. Obstfeld and Rogoff (1995) show that a monetary shock increases the DPV of utility by the same amount in both countries. On the other hand, Corsetti and Pesenti (2001), and Tille (2001), find that the gains in domestic output are more than offset by deteriorating terms of trade, if the cross-country substitutability is low. In this paper, we have shown that these frameworks in the end generate a common result: A monetary shock is a beggar-thyself policy in the short run, whether the cross-country substitutability is equal to or is smaller than the within-country substitutability.

\section{Conclusions}

In this paper, we examined the question of whether an expansionary monetary policy is beggar-thy-neighbour or beggar-thyself, within the context of a standard open-economy model with imperfect competition and nominal rigidities. Prior research has shed light only on the discounted present value of welfare, an approach which misses the potentially important time dimension. It has shown that the cross-country substitutability is a key parameter governing the international welfare effects of monetary policy. Using a more advanced method for welfare analysis, we show that, in the short-run, such a policy is beggar-thyself, and that this result does not depend on the size of the cross-country substitutability. In the rest of the world, welfare increases in the short-run, while long-run effects depend on the cross-country substitutability both at home and abroad.

Superficially, one could conclude that the recent expansionary monetary policies of the U.S. Federal Reserve and the European Central Bank can 
be expected to increase welfare only after some time. However, this policy stance was a reaction to a severe recession, whereas our results are based on the assumption of full employment. Therefore, a crucial assumption for the welfare criterion employed is that monopolistic competition and price rigidities are the only distortions. Extending the model to allow for involuntary unemployment due to labour market inefficiencies would be an interesting extension, and is left for future research. 


\section{References}

[1] Betts, C. \& Devereux, M. (2000): Exchange Rate Dynamics in a Model of Pricing-to-Market. Journal of International Economics, 50, 215-244.

[2] Calvo, G. (1983): Staggered Prices in a Utility Maximizing Framework. Journal of Monetary Economics, 12, 383-398.

[3] Corsetti G., (2007): New Open Economy Macroeconomics. European University Institute Working Papers, Robert Schuman Center for Advanced Studies 2007/27.

[4] Corsetti, G. \& Pesenti, P. (2001): Welfare and Macroeconomic Interdependence. Quarterly Journal of Economics, 116, 421-455.

[5] Ganelli, G. \& Tervala, J. (2010): Public Infrastructures, Public Consumption, and Welfare in a New-Open-Economy-Macro Model. Journal of Macroeconomics, forthcoming.

[6] Klein, P. (2000): Using the Generalized Schur Form to Solve a Multivariate Linear Rational Expectations Model. Journal of Economic Dynamics \&5 Control, 24, 1405-1423.

[7] Lane, P. (2001): The New Open Economy Macroeconomics: A Survey. Journal of International Economics, 54, 235-266.

[8] Lane, P. \& Ganelli, G. (2003): Dynamic General Equilibrium Analysis: The Open Economy Dimension. In Altug, S., Chanda, J. \& Nolan, C. (eds.) Dynamic Macroeconomic Analysis. Cambridge University Press, Cambridge.

[9] McCallum, B. (2001): Software for RE Analysis. Computer software available at http://wpweb2.tepper.cmu.edu/faculty/mccallum/research.html

[10] Obstfeld, M. \& Rogoff, K. (1995): Exchange Rate Dynamics Redux. Journal of Political Economy, 103, 624-660. 
[11] Obstfeld, M. \& Rogoff, K. (1996): Foundations of International Macroeconomics. MIT Press, Cambridge.

[12] Pierdzioch, C. (2006): Capital Mobility, Consumption Substitutability and the Effects of Monetary Policy in Open Economics. German Economic Review, 6, 79-94.

[13] Tille, C. (2001): The Role of Consumption Substitutability in the International Transmission of Monetary Shocks. Journal of International Economics, 53, 421-444.

[14] Tille, C. (2008): Financial Integration and the Wealth Effect of Exchange Rate Fluctuations. Journal of International Economics, 75, 283294.

[15] Tervala, J. (2010): The International Transmission of Monetary Policy in a Dollar Pricing Model. Open Economies Review, forthcoming.

[16] Warnock, F. (2003): Exchange Rate Dynamics and the Welfare Effects of Monetary Policy in a Two-Country Model with Home-Product Bias. Journal of International Money and Finance, 22, 343-363. 
Figure 1: Effects of a Monetary Shock in the Basic Case $(\rho=\theta=6)$
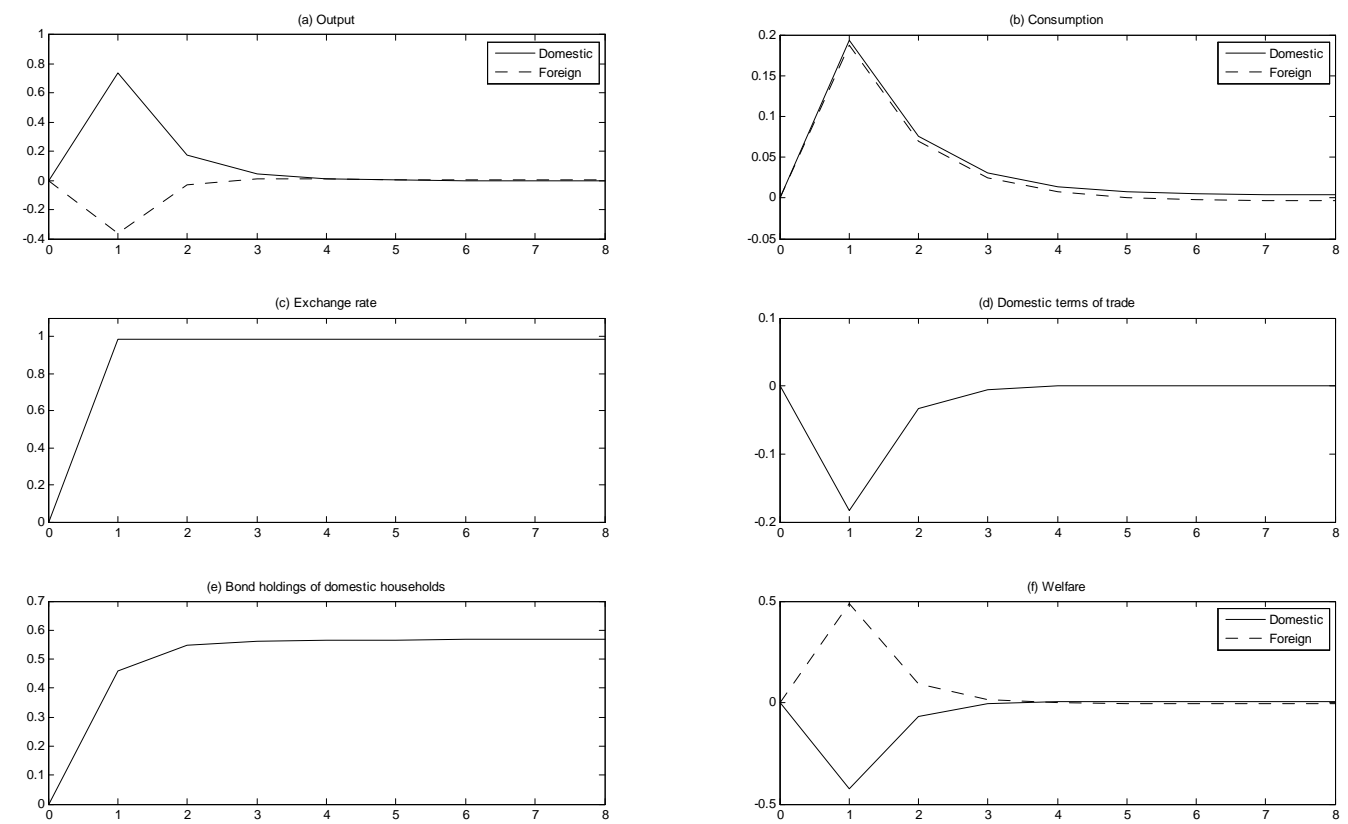
Figure 2: Low Cross-Country Elasticity
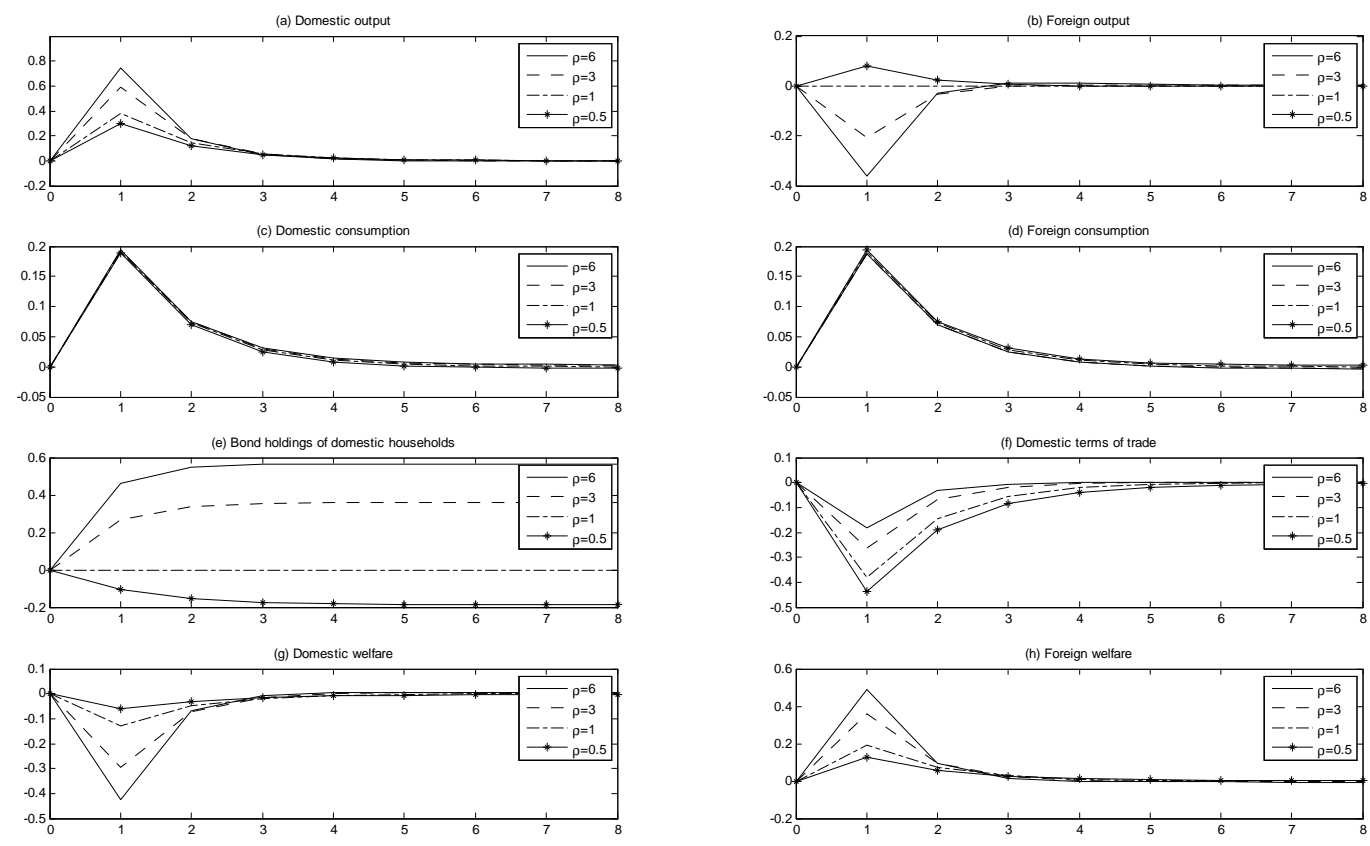


\section{Diskussionsbeiträge des Fachbereichs Wirtschaftswissenschaft der Freien Universität Berlin}

2010

2010/1 BÖNKE, Timm / Sebastian EICHFELDER

Horizontal equity in the German tax-benefit system

Economics

2010/2 BECKER, Sascha / Dieter NAUTZ

Inflation, Price Dispersion and Market Integration through the Lens of a Monetary Search Model

Economics

2010/3 CORNEO, Giacomo / Matthias KEESE / Carsten SCHRÖDER The Effect of Saving Subsidies on Household Saving

Economics

2010/4 BÖNKE, Timm / Carsten SCHRÖDER / Clive WERDT

Compiling a Harmonized Database from Germany's 1978 to 2003

Sample Surveys of Income and Expenditure

Economics

2010/5 CORNEO, Giacomo

Nationalism, Cognitive Ability, and Interpersonal Relations

Economics

$2010 / 6$

TERVALA, Juha / Philipp ENGLER

Beggar-Thyself or Beggar-Thy-Neighbour?

Economics 